\title{
Wiedza w wierszu. Filozofia czasu postlirycznego
}

\author{
Jakub Momro
}

TEKSTY DRUGIE 2020, NR 5, S. 73-95

DOI: 10.18318/td.2020.5.6 | ORCID: 0000-0003-2479-0599

Nadzieja to nie utrwalone wspomnienie, lecz powrót tego, co zostało zapomniane.

T.W. Adorno ${ }^{1}$

Doskonałość przetrwa długo dzięki znanym pieśniom, lecz niewielu umie to sprawić.

Pindar $^{2}$

\section{1.}

Bodaj największym odkryciem nowoczesnej liryki jest zdolność do integracji języka z wolnością. W tym zestroju artykulacja jednostkowości łączy się z politycznym

1 T.W. Adorno Parataksa. O późnej liryce Höldelrina, w: tegoż O literaturze. Wybór esejów, przeł. A. Wołkowicz, Czytelnik, Warszawa 2005, S. 92.

2 Pindar Trzecia Oda Pytyjska, przeł. A. Szastyńska-Siemion, w: tegoż, Wybór poezji, opr. A. Szastyńska-Siemion, Ossolineum, WrocławWarszawa-Kraków-Gdańsk-Łódź 1981, s. 99.
Jakub Momro -

profesor na Wydziale Polonistyki UJ, filozof, literaturoznawca, eseista i tłumacz (m.in.). Derrida, P. Lacoue-Labarthe, J.-L. Nancy, J. Kristeva, R. Barthes, P. Szendy). Autor książek: Literatura świadomości. Samuel Beckett podmiot - negatywność (2010, wyd. angielskie: Literature of Consciousness. Samuel Beckett Subject-Negativity, 2015), Widmontologie nowoczesności. Genezy (2014), Ucho nie ma powieki. Dźwiękowe sceny pierwotne (2020). Członek redakcji „Tekstów Drugich" i Komitetu Redakcyjnego serii "Nowa Humanistyka". 
programem emancypacji. To, jak się zdaje, wciąż lekcja nieodrobiona i nieprzedawniona. Wraz z pojawieniem się w historii myśli i literatury Hölderlina, Schellinga i Hegla w ich wielogłosie rozpoczyna się zarówno historyczne, jak i idealistycznie warunkowane myślenie o poezji jako przezwyciężeniu sprzeczności, tkwiących w relacji idei i doświadczenia, zmysłowej przyjemności i apriorycznego pojęcia piękna.

Jak twierdził kilkadziesiąt lat po pierwszych pracach niemieckich idealistów Stendhal, może ono istnieć jedynie jako „obietnica szczęścia”. W owej quasi-tezie autora Pustelni parmeńskiej tkwi zasada nowoczesnej poezji, która wyzbywszy się metafizyki jako zasady zachowania komunikacji i języka w ogólności, przekształca wszelką bezforemność i zmienność materii świata w pojęcie, którego jedynym celem jest prawda. To właśnie ona zajmuje pozycję hegemoniczną, ponieważ - w projekcie idealistów - stanowi konkretną syntezę ludzkich działań, refleksji i afektów. „Prawda jest konkretna”, powie z kolei sto lat po Hölderlinie, Heglu i Marksie Bertolt Brecht, trafiając w samo sedno wielkiej rewizji filozoficznej, estetycznej i egzystencjalnej późnej nowoczesności: historia człowieka to także historia naturalna życia w różnych jego odmianach, łącząca się w czasowo motywowanych aktach wglądu i procesach uświadomienia. Tę konkretność widać w dwóch przemieszczeniach w obrębie myśli. Po pierwsze, celem podmiotu, istniejącego tylko o tyle, o ile urzeczywistnia się on w akcie artykulacji, jest przemiana w pojęcie. Innymi słowy, podmiot przestaje istnieć jako subiektywność, nie w tym sensie jednak, że przeobraża się w czyste myślenie, lecz dlatego, że sam z siebie, w akcie refleksyjnej destrukcji, ujawnia własną arbitralność i inkongruencję. W tym miejscu działa już spekulatywne odwrócenie pokazujące, że to pojęcie staje się podmiotem, który - w takiej właśnie postaci - ustanawia pełną suwerenność. Nie rozwiązuje to jednak dylematu antytetycznej jednostkowości, z jej lękami, pragnieniami, nerwicami, rozkoszami i bólem. Jednostkowość przegląda się w lustrze doskonałej uniwersalności pojęcia (będącego pojęciem jako takim, pozbawionym swego obiektowego odniesienia), ale zarazem taka pojęciowość bez dialektycznych napięć naruszających i poruszających arcyludzką subiektywność okazuje się pustą abstrakcją. Toteż (to drugie przemieszczenie) nie istnieje już forma usprawiedliwienia indywidualnego i zbiorowego istnienia i wiedzy, która dałaby się wyprowadzić z jakiejkolwiek metafizyki. Idealizm, wraz z jego materialistycznymi rewizjami, unieważnia (w sensie logicznym, epistemologicznym, a przede wszystkim egzystencjalnym) wszelką metafizykę, w jej miejsce podstawiając napięcie między skończonością a nieskończonością. 
To już zatem inny świat życia i inna rzeczywistość poetycka. Nowa poezja ma stanowić „pojednanie w różnicy”, więc gra językowa w jej obrębie staje się zarówno postmetafizyczna, jak i postlitryczna. Nie unicestwiając jednostkowej artykulacji na stałe, wiąże ją z powszechnością doświadczenia (politycznego czy społecznego), uniwersalnego pojęcia i towarzyszącej mu pracy krytycznej, czyli popędem sądzenia. W miejsce metafory, będącej odpowiednikiem, reprezentacją, homologią, strukturą czy zasadą metafizyki, w wierszu pojawia się wiedza, która ukonkretnia prawdę - sprzeczną, ale właśnie dlatego utrzymującą poezję przy życiu. Skoro tak, to nieskończoność nie ma żadnego transcendentnego uprawomocnienia i umocowania, lecz wpisana jest w model myśli skończonej. Jeśli egzystencja stanowi czystą skończoność, to poezja stanowi granicę i kres tej skończoności, zapisane w znakach i znamionach, w głosie i literze. Tę niezwykle złożoną rzeczywistość bodaj najpełniej widać w poezji Hölderlina, zwłaszcza we wczesnym okresie, kiedy poezja jako taka, jako projekt innego świata, nie została jeszcze w żaden sposób zdefiniowana. Toteż Hölderlin pisze wiersze, choć nie tworzy jeszcze „poezji”. Spójrzmy na Lakoniczność, utwór z 1789 roku:

„Czemuś tak lakoniczny? Nie cieszy cię już śpiew?

W młodości, w dniach nadziei,

Nigdy nie chciałeś kończyć,

Twa pieśń nie znała kresu".

Pieśń to oblicze szczęścia. - Kąpać się w łunie wieczoru?

Zresztą już chłodno na ziemi,

I nocny ptak furkocze

Tuż przed twoimi oczyma. ${ }^{3}$

Lakoniczność pełni tu funkcję inskrypcji, śladowego zapisu minionego czasu. Rzeczona celność i zwięzłość to również znamię bezwzględnej, nieodwracalnej dojrzałości. To właśnie ta gorzka samoświadomość okazuje się największą ideologiczną fikcją, zasłoną pozornej pewności i doskonałej samowiedzy. Inicjalne pytania tyleż dotyczą podstawowej sytuacji mówienia (ja i ty), co stanowią gest nieudanego, niemal protokolarnego przypominania przeszłości, nie jako stanu świata, lecz jako dynamiki nieskończonego

3 F. Hölderlin Lakoniczność, w: tegoż Co się ostaje, ustanawiają poeci, przeł. A. Libera, Znak, Kraków 2003 , s. 43. Bliźniaczo podobny jest wiersz Dawniej i dzisiaj, również z 1798 roku. 
przyrostu życia. Dzieje się tak dzięki pieśni, zamkniętej, jak u ukochanego przez samego poetę Pindara, w epigramatycznej formule, już wyzwolonej spod władzy subiektywności. Owe „dni nadziei” przepadają jakoby w czasie teraźniejszym, w wyzbytych liryzmu dniach młodości. Przeszłość nie jest tylko mitologią pełni i bezpośredniości, ponieważ wiersz może przybierać kształt złej nieskończoności, solipsyzmu lub narcystycznej gry, a aktualność nie stanowi już pustego trwania w odróżnicowanej, zmaterializowanej i obiektowej naturze. Hölderlin tworzy więc podwójną niemożliwość, wprawia w ruch podwójną negację, oddając jednakże ostatnie słowo samej poezji - wyjściowa antyteza osiąga kres, jednak nie tam, gdzie samą pieśń moglibyśmy usłyszeć, to znaczy w mitycznym i nieokreślonym głosie przenikającym młodzieńczą ekspresję. Tak bodaj należałoby rozumieć słynny „zwrot w stronę ziemi”, o którym po wielokroć pisze Hölderlin: słowo powraca jako rozedrgany, poliwalentny obiekt, który nie jest już metaforą, ale jeszcze nie jest „nową" formą, choć stanowi wyraz trzeźwości rozumu, nie odbiera nadziei ostatecznie, lecz ją przemieszcza.

W ten sposób odległa prawda lirycznej pieśni przeobraża się w realność tego, co bliskie, co pojawia się „tuż obok twoimi oczami”. Ów podwójny adres (do wewnętrznego rozmówcy i czytelnika) pozwala wyeksponować zmysłowość świata, o którym zapomina się wtedy, gdy wybrzmiewa pierwotna poezja. Kiedy więc Hölderlin w odniesieniu do starożytnych pisał o naśladowaniu, które nie może się ziścić, definiował nowoczesność, rzeczywistość pozbawioną metafizycznego lub mimetycznego gruntu. Poeta nie tylko traci bezpieczeństwo („Lecz gdzie niebezpieczeństwo, tam i wybawienie”) ${ }^{4}$, ale też uwalnia się od krępujących go więzów archaicznej prawdy, zaklętej w magicznych mistyfikacjach poezji jako lirycznej pieśni. Ta antynomia zapętla się w rodzaj topologicznej wstęgi, immanentnej powierzchni języka, który nie ma żadnej społecznej, ani transcendentnej legitymizacji. Słowo jest oznaką wspomnienia lub zapowiedzią przyszłości, rozpoznaniem lub nadzieją. Poetycka mowa wyłania się z arcyludzkiej ambiwalencji i niejako do niej powraca. Skoro bogowie już odeszli ze świata, to poezja może pełnić - na dobre i złe - funkcję antropologii epoki postmetafizycznej. Fantazja na temat „innej sceny”, ,pieśni, która nie zna kresu”, stanowi odwrotność twardego prawa, głoszącego, że Bóg jest martwy. Zadanie poetyckie, jakie wyznacza sobie Hölderlin, polega więc na utrzymaniu owego ruchu po wstędze, a zarazem odkryciu miejsc, w których ów ruch się zatrzymuje, gdzie coś wytrąca nas

4 F. Hölderlin Patmos, w: tegoż Co się ostaje, ustanawiają poeci. 
i prawdę w wierszu z logicznych, poznawczych i percepcyjnych oczywistości - miejsc, gdzie nie można przyswoić tego, co własne, oraz odseparować się od tego, co dalekie. Poezja może żyć zatem pod warunkiem, że nie będzie się opierała na lamentacji utraty, lecz przyjmie prawo literatury, w którym „by tem ducha jest ko śc c”', a wiersz - obiektem, wokół którego krążą znaczenia, doznania i pojęcia.

Głos Hölderlina jest pod tym względem niesamowicie wręcz konsekwentny. Podział na dwie strofy sugeruje precyzyjną dwudzielność obrazów świata. Tymczasem między nimi pojawia się uskok, szczelina, w której cytat z zaprzeszłej rozmowy, intensyfikujący dodatkowo muzyczną wartość lirycznej ekspresji, odbija się w tezie. Ta z a ś, mówiąc to samo („Piękno to oblicze szczęścia"), dokonuje inwersji w obrębie rzeczywistości, ujawniającej się dzięki wierszowi. Teza, po której pojawia się pytanie wprowadzające w inny świat, niejako wypełniony dystansem tego, co bliskie. Antytetyczność wiersza nie zna kresu, ale w ramach swej materialności, zmysłowości oraz zmienności, której nie sposób powstrzymać. Figura ptaka „furkoczącego" przed oczyma to figura spekulatywnej poezji, która wprawiając w ruch dialektykę bliskości i oddalenia, daje czy choćby podtrzymuje nadzieję na wolność. Przypomnijmy sobie raz jeszcze wstęgę Moebiusa: poruszający się owad raz po raz odkrywa, że „inna” strona jest odwróconą, odkształconą tą samą stroną, na której się znajduje ${ }^{6}$. Ta chwila deziluzji i zatrzymania oraz niepowstrzymanego ruchu w ciągu dalszych złudzeń i ich demistyfikacji poświadcza coś, co można określić - za Alenką Zupančič - „fizyką nieskończoności"7. Wiersz jest nieskończony, ponieważ emancypuje jednostkowość z jej subiektywnych, narcystycznych przeświadczeń, przechodzi - mówiąc za Hölderlinem i Heglem - ze świata bezczasowej pięknej duszy do samowiedzy, która odkrywa dla wiersza jego własny czas. Jeśli Hegel w swym słynnym powiedzeniu, stwierdzał, że sowa Minerwy wylatuje za późno, że mądrość jest wiecznym l'esprit d'escalier, to Hölderlin, pisząc o „nocnym ptaku”, wystawia nas na działanie niedającej się zatrzymać teraźniejszości i niemożliwej do wyobrażenia przyszłości, czasu, dla którego nie istnieje jeszcze imię. Tak jak wiersz, ów czas to podziurawiona, niekompletna nieskończoność, ujawniająca się nie gdzieś daleko, lecz „tuż przed oczyma”, w ruchu i stawaniu się

5 Por. G.W.F. Hegel Fenomenologia ducha, przeł. Ś.F. Nowicki, Aletheia, Warszawa 2002, s. 230.

6 Por. J. Lacan Le Séminaire X. L'angoisse, Seuil, Paris 2004.

7 Por. A. Zupančič Te Odd One In. On Comedy, MIT, London-New York 2008. 
jednostek i zbiorowości. Rosnące życie, które przeobraża się w pieśń, okazuje się zestrojone ze zmianą polityczną, w szerokim znaczeniu tego słowa.

Jeśli dla Kleista lektura Krytyki czystego rozumu była przemianą świadomości tłumaczącą rewolucyjną zmianę świata społecznego i historycznego, to dla Hölderlina wieczna kraina Hesperii co i rusz odsłania swą mroczną, mitologiczną oraz - ostatecznie - fałszywą stronę. W Buonapartem poeta, pojmowany jako najintensywniejsza postać egzystencjalna, odwraca ducha rewolucji w historyczny konkret aktualności. Z niej właśnie wysnuwać się może radykalna zmiana polityczna („On w pieśni żyć nie może i nie będzie. / On żyje i zostanie tylko w świecie"). Hölderlin nie zamyka wiersza w nieskończoności matematycznej czy teoretycznej. Natrętne, wręcz neurotyczne gesty formalizacji poetyckiej widoczne są od samego początku: począwszy od gnomicznych inskrypcji-epigramatów, do pewnego stopnia naśladujących antyczną zwięzłość, a kończąc na rytmicznym szaleństwie hymnów.To jednak tylko jedna strona poetyckiej ontologii. Zza doskonałości formuły poetyckiej wyziera spękana, chropawa podmiotowość, która nieustannie pragnąc, domaga się miłości. Ten wielki temat Hölderlina wybrzmiewa wtedy, gdy najpełniej w epigramach i krótkich odach - lęk i melancholia w mocnych stanach skupienia, zgęstniałe i często nie do zniesienia dekonstruują niemal wszystkie formy negatywnego, a przez to perwersyjnego narcyzmu. Istnienie zwrócone w stronę „ziemi”, elementarnej biomorficznej postaci, sprawia, że domaganie się miłości i relacji z Innym tworzy konkretną treść poetyckich gestów. W tym sensie pozostaje ona otwarta. Inaczej niż chciałby Heidegger czy Agamben, otwarte nie wiąże się z granicami (między animalnością a człowieczeństwem, racjonalnością a szaleństwem, wnętrzem a zewnętrzem świadomości) ${ }^{8}$, lecz z procesem myślenia jako skończoną operacją dokonywaną na cielesnej, czującej, afektywnej egzystencji - ludzkiej i nieludzkiej. To dotyk lub jego brak konstytuuje otwarcie, zarówno robi wyrwę w ruchu transcendowania, jak i rozrywa na części spójny świat podmiotu. W tym sensie wiersz Hölderlina okazuje się polem transimmanencji, a więc przechodniości; poezja ucieleśnia „myśl skończoną absolutnie”, czyli taką, która nie pozostaje „zamknięta w pojęciu nieskończoności”.

Dzięki temu zasklepiona w pewnych warunkach historycznych (epigramat antyczny przeniesiony w epokę nowoczesną) reguła pisania okazuje się nieoczekiwanie i zdarzeniowo miejscem dosłownej, a nie symbolicznej

\footnotetext{
8 Por. G. Agamben Otwarte, przeł. P. Mościcki, „Krytyka Polityczna” 2008 nr 1.

9 J.-L. Nancy Une pensée finie, Galilée, Paris 1990, s. 48.
} 
metamorfozy. Z jednej strony, na co często zwraca się uwagę, to przemiana "ducha w Ducha”, a z drugiej (o czym mówi się rzadziej) - to konwersja afektów, będących zaprzeczeniem absolutu, liczebnej syntezy w postaci fetyszu Jednego, owego - jak głosi tytuł jednego z najważniejszych logicznie epigramatów - „źródła wszelkiego zła”10. A zatem niejako pod podszewką wiersza tętni życie wielości, która nie tyle otwiera, ile ujawnia się jako fizyka nieskończoności, naturalny i ludzki proces identyfikacji i wyobcowania z własnych doświadczeń. Na tym też polega radykalny ateizm Hölderlina, który uznaje, że choć żadna restytucja rajskiego porządku nie jest możliwa, to właśnie w tej niemożności ustanawia się pragnienie życia zwielokrotnionego w poezji. O tym przecież mówi Mnemosyne, przewrotna pochwała niepamięci jako warunku życia, niemożności wspominania i odrzucenia wiecznej żałoby jako patologicznego stanu istnienia. A ono samo? Rozpięte jest między przestrzennym bezmiarem i nieskończonością sądu. „Bycie wiernym" to nie tyle slogan etyczny, ile epistemologiczny i ontologiczny warunek egzystencji:

A my nie chcemy patrzyć

Ani wprzód, ani wstecz.

Tylko się kołyszemy

Niby w łódce na morzu. ${ }^{11}$

Nie ma więc „innej sceny”, czyli nie ma odwołania od stanu, w którym boskość nie podlegałaby żadnej pracy pamięci, ponieważ wiersz nowoczesny rozstraja tautologiczny mechanizm „wspomnienia" (przypominam sobie to, co jest anonimową i uprzednią wiedzą) - kres pamięci jako ocalenia stanowi zarazem początek poezji jako dialektycznej ekspresji narcyzmu i miłości. Tak też rozpoczyna się proces upodmiotowienia. Czy może dziwić, że na jego figurę Hölderlin wybiera Sofoklesa? Postać, w której ta dialektyka odcisnęła, $\mathrm{w}$ dosłownym sensie, piętno na ciele.

Radość starało się wielu wyrazić radością radość, daremnie.

Dopiero tu ją znajduję, dopiero tu - w tym smutku. ${ }^{12}$

\footnotetext{
10 F. Hölderlin Źródło wszelkiego zła, w: tegoż Co się ostaje, ustanawiają poeci, s. 67.

11 F. Hölderlin Mnemosyne, w: tamże, s. 237.

F. Hölderlin Sofokles, w: tamże, s. 67.
} 
Pojęcie smutku staje się tu smutkiem samym, emocją, poruszeniem i dotknięciem samego sedna wiersza, który ożywa o tyle, o ile swoją tożsamość (logiczną i poetologiczną) rozbija w pył przez ciąg nieskończonych różnicowań. Dlatego właśnie smutek nie może być ostatecznym punktem procesu samowiedzy - nieokreślony stan popycha Sofoklesa, prefigurację podmiotu nowoczesnego, w stronę afirmacji życia poróżnionego i antytetycznego. Smutek nie jest ani nieszczęściem, ani żałobą, lecz stanem istnienia i - jako taki - nie daje się zdefiniować ani ograniczyć. Drugim bohaterem tych przygód jednostkowości, wiedzy i wiersza jest Hyperion. To ten, który niesie z sobą Los oraz stanowi zarazem jego alegorię - to życie i jego formuła spleciona w jedno w doświadczeniu egzystencjalnej degradacji. Los to, oczywiście, konieczność naturalna, a nie metafizyczna, ale także - prawdziwy kres procesu upodmiotowienia, to rozpoznanie, które było niedostępne Sofoklesowi. Pieśń inkorporuje te wszystkie własności losu, stając się materialnym znamieniem, jakby wiersz - carmen figuratum - przeobrażał się wraz z pisaniem i czytaniem, wraz z rytmem artykulacji w sekret myśli.

Nam zaś nie dane jest

Zagrzać gdziekolwiek miejsca.

My, ludzie, cierpiąc, znikamy,

Spadamy gdzieś na oślep -

Z godziny na godzinę,

Jak woda

Z progów skalnych,

Przez wszystkie nasze lata -

W nieodgadniony dół. ${ }^{13}$

Los uosabiany przez Hyperiona urzeczywistnia się w stałym i dziwnym ruchu ku otchłannej niewiedzy. Trudno więc mówić w tym wypadku o mocnym determinizmie; wiersz Hölderlina nie mówi o upadku, lecz o koniecznej (choć wprzódy czysto negatywnej) wolności. Sprzeczność pozostaje nierozwiązywalna, zanikanie bez śladu to nie tyle śmierć, ile rozpoznanie własnej skończoności. Naturalny ruch „spadania” paradoksalnie staje się wyzwoleniem, płynność indywidualnego życia wchodzi w złożoną osobliwą wspólnotę śmiertelnych - ich istnienie usprawiedliwione jest przez epistemologiczny popęd. Wiersz staje się zarysem kresu, jak i teoriopoznawczą rozprawą na

13 F. Hölderlin Hyperiona pieśń losu, w: tegoż Co się ostaje, ustanawiają poeci, 77. 
jego temat. Tam zatem, gdzie kończy się liryczna ekspresja, ma początek materialna skończoność wiersza, tam też jednostkowość zaczyna wyrażać się w świecie doświadczenia, które przestało być naturalne.

W tym sensie Hölderlin pozostaje, przynajmniej do pewnego stopnia, wierny intuicjom z Najstarszego programu systemu niemieckiego idealizmu. Kluczowa kulturowa i antropologiczna zmiana, jaka dokonuje się w tym tekście, polega na przejściu „od natury do ludzkiego dzieła”. Spośród trzech autorów tego manifestu jedynie Hölderlin lokował swoją poetycką spekulację w tym przesunięciu. Dzieje się tak, dlatego że nie istnieje wiersz bez swej czysto literalnej podstawy, a zwrot w stronę materialności pisma okazuje się jednocześnie rozproszeniem ducha w świecie mowy, jego twórczą dekonstrukcją, która bardziej niż na polisemii polega na radykalnemu różnicowaniu. Różnica pochodzi wszelako od ducha, rozumianego tutaj jako zdolność do tworzenia dzieła sztuki, do uczynienia z poezji języka krytycznej samowiedzy. Czy taki projekt mógł się udać? Czy właśnie nie dlatego obłęd poety musiał poprzedzić szaleństwo, jakiemu uległa sama poezja? To wiersz bowiem staje się podmiotem, wieloraką substancją życia, na której niejako ciąży obowiązek prawdy jako jedności, a nie konkretu. Hölderlin inaczej niż Hegel, konstruujący swój system na podstawie logicznej sprzeczności, z której zrodziła się nauka logiki, owa wielka opera rozumu (Lacoue-Labarthe) ${ }^{14}$ lub wielka komedia racjonalności (Brecht) ${ }^{15}$, w swej poezji eksponuje sprzeczności tego systemu, zestawiając ze sobą literę i pojęcie. Lacoue-Labarthe z pewnością ma rację, że właśnie w tej zasadzie demonstracji, wystawienia, ekshibicji tkwi nie tylko reguła podwójnego wiązania owych skrajności, lecz „zagrożenie psychozą"16. Skoro wiersz staje się substancją prawdy, jeśli w związku z tym przemienia się w jedynego bohatera, przezwyciężającego ontologiczną nicość („nieodgadniony dół”) i logiczną negatywność (która zawiesza samą zasadę zniesienia), psychotyczna separacja od świata, chorobliwe „oddalenie” jednostki od rzeczywistości, o którym pisze poeta, okazuje się właściwym środowiskiem nowoczesnego podmiotu.

A przecież temu stanowi świata towarzyszy poznawczy gest, w zamiarze ocalający osobliwości naszych losów. Życie jest, jak głosi Najstarszy program,

14 Por. P. Lacoue-Labarthe Pour n'en pas finir. Écrits sur la musique, Christian Bourgois, Paris 2015, S. 259.

15 Por. B. Brecht Rozmowy uchodźców, przeł. R. Szydłowski, PIW, Warszawa, 1969, s. 108.

16 Por. P. Lacoue-Labarthe Hölderlin i Grecy, w: tegoż Typografie, przeł. J. Momro, A. Zawadzki, Universitas, Kraków 2004, S. 240. 
najpierw fizyką, którą należy powiązać z eksperymentem egzystencjalnym, na koniec zaś z estetycznym: „Gdy filozofia wskaże idee, doświadczenie, dane, będziemy mogli w końcu mieć fizykę, jakiej oczekuję od późniejszych epok. Nie wydaje się, by dzisiejsza fizyka mogła zadowolić twórczego ducha, jakim nasz duch jest czy powinien być"17. Jeśli więc poezja przyszłości ma spełniać swoją antropologiczną i historyczną (a niekiedy również historiozoficzną)funkcję, należy przyjąć, że nieskończoność duchów nie oznacza ich nieśmiertelności. Stąd konieczność ustanowienia literalnej i zmysłowej podstawy ludzkiej rzeczywistości, tak by możliwe stała się faktyczna, a nie postulowana czy projektowana, absolutna wolność duchów w wielości ich przejawów oraz światów. Na pozór w samym manifeście idealizmu na plan pierwszy wysuwa się piękno rozumiane dość tradycyjnie na sposób platoński, jako idea przekraczająca wąsko rozumianą racjonalność „tabel i wykazów". Co oznacza dość arbitralnie włączona w sam środek filozoficznego przecież dyskursu teza, że „filozofia ducha jest filozofią estetyczną”? Pytanie to tym dziwniejsze, że sama estetyka nie jest ani określoną domeną ducha, ani porządkiem współobecności wolnych podmiotów w zmysłowym świecie, lecz po raz kolejny za pomocą apodyktycznego gestu zostaje wyłączona z myśli na rzecz poezji, która ma zajmować na stałe pozycję "nauczycielki ludzkości".

Ale czego może poezja nauczyć? I kogo? Na drugie pytanie autorzy odpowiadają dość precyzyjnie, gdy definiują emancypację i samostanowienie ludu, który wyzwala się spod panowania wielkiego Innego. Poezja staje się wówczas imperatywem moralnym czy etycznym: „Nigdy pogardliwego spojrzenia, nigdy ślepego drżenia ludu przed jego mędrcami i kapłanami"18. A zatem chodzi tu bardziej o rewolucję niż mieszczański ideał Bildung. Czy wobec tego można udzielić odpowiedzi na pierwsze pytanie? Co znaczy wizja przyszłości, w której „nie będzie już filozofii, nie będzie już historii, jedynie sztuka poetycka przeżyje pozostałe nauki i sztuki"? ${ }^{19} \mathrm{Z}$ pewnością dla Hegla poezja byłaby pojednaniem zmysłowości z Ideą, za pośrednictwem kolizji wrażeń i pojęć. Jak mówi Jean Hyppolite: „Według Hegla język to byt jako byt-w sobie, który nie istnieje inaczej jako równocześnie byt jednostkowy

17 G.W.F. Hegel Najstarszy program systemu niemieckiego idealizmu, w: tegoż Pisma wczesne z filozofii religii, przeł. G. Sowinski, Znak, Kraków 1999, s. 275.

18 Tamże.

19 Tamże, s. 276. 
i powszechny"20. Tym byłaby mądrość, dzięki której poezja z formuły języka, a więc znaczeniowego zapośredniczenia, przeobraziłaby się w jednokładny punkt absolutnej samowiedzy - ducha, który powróciłby do siebie, u kresu czasów „puszczając wolno", jak mówi filozof, wszystkie sprzeczności, które dręczyły człowieka nowoczesnego. Ta, by tak rzec, konserwatywna superfikcja epistemologiczna pozbawia więc wywrotowej i życiodajnej mocy poezję, która - jak można wyczytać z wierszy Hölderlina - żyje z niepojednania i różnicowania. Nie chodzi bowiem tylko o tę mityczną niemal, a w każdym razie kliniczną sytuację utraty zmysłów ${ }^{21}$, lecz o siłę języka, w którym subiektywnej ekspresji nieodłącznie towarzyszy artykulacja tez o rzeczywistości. Radykalność antyliryzmu Hölderlina polega na tym, że bez zestroju tych dwóch elementów, nawet jeśli grozi to psychotyczną dysocjacją, nie istnieje poezja, która mogłaby przekroczyć stare formuły mitologii języka i obrazowania. Dość spojrzeć na jedno ze świadectw tego radykalizmu, jeden z ostatnich wierszy, Przekonanie:
Zakorzeniona mocno w duchu wiedza
Jest dla człowieka niczym światło dnia -
Ta boska jasność, która świat nawiedza
I jego ciemność przenika do dna. ${ }^{22}$

2.

Być może właśnie dlatego nie ma większej mistyfikacji w historii poezji niż ideologiczny komunał, w który zamieniono frazy Hölderlina, czyniąc z nich wyraz bezczasowej uniwersalności liryki. Być może też ta fałszywa lekcja, jaką wyciągnięto z rewoltującego, nieustannie przemiennego ruchu myśli w samym wierszu, pozwoliła unicestwić sporą część naszej refleksji o radykalnej, bezwzględnej krytycznie poezji, która może pozostać poezją, o ile tworzy wiedzę i się nią staje. W tym kontekście zadziwiający jest rodzaj celowego, jak się zdaje, zerwania, jakiego dokonuje Martin Heidegger, między krytyczną poezją Hölderlina a wyrosłą na podstawach spekulatywnego

20 J. Hyppolite Logique et existence, PUF, Paris 1952, s. 57. Przeł. J.M.

Por. K. Jaspers Strindberg i Van Gogh. Próba analizy patograficznej z przywołaniem Swedenborga i Hölderlina, przeł. R. Reszke, KR, Warszawa 2006, s. 163-184; J. Laplanche Hölderlin et question du père, PUF, Paris 1961. 
idealizmu dialektyczną świadomością wiedzy. W obszernej i drobiazgowej analizie Fenomenologii ducha Heidegger śledzi kolejne etapy wyłaniania się świadomości jako doświadczenia świata i eksperymentalnej wiedzy podmiotu, stającego się samowiedzą. Przyjmując swego rodzaju teatralność epopei ducha, a więc powstawanie świadomości siebie jako (dysjunktywnej) syntezy tego, co własne, i tego, co inne, wskazuje na konieczną dowolność gestu teoretycznego: aby myślenie mogło stać się pewne, musi - z zasady - przeobrazić się w to, co absolutne, a więc to, co nie potrzebuje potwierdzenia: „[...] jedynie absolut jest prawdziwy. Jedynie to, co prawdziwe, jest absolutne. Zdania te wprowadzone są bez uzasadnienia. [...] Te zdania są nieuzasadnione, ale nie ma w tym nic arbitralnego w sensie dowolnego wypowiadania twierdzeń. Te zdania są nieuzasadnialne"23.

W tej trzeźwej i trafnej analizie absolutu jako czystego pojęcia Heidegger sprytnie włącza własną metaforę, będącą do pewnego stopnia odwrotnością metafory Otwartego, braku podstawy wraz z jej wariantem w postaci ontologicznej otchłani (określanej przez samego filozofa mianem „ugruntowania” lub jego braku). Zmienia to w zasadniczy sposób całą interpretację nie tylko Hegla, ale i w takim samym stopniu poezji Hölderlina. Heidegger przemilcza bowiem fakt, że owa niemożliwość uzasadnienia twierdzeń o absolucie rzeczywistości nie polega na tym, że są to tezy odnoszące się do metafizyki czasowości; nie chodzi zatem o kres dziejów ani o źródłowość doświadczenia świadomości, gdyż w perspektywie dialektycznej zarówno koniec czasów, jak i geneza, nie istnieją - ani w postaci apriorycznej, ani w postaci treściowej. Innymi słowy, Heidegger popada w patos niewyrażalności, przed którym - jako filozof - przestrzegał Hegel, a o czym - jako poeta - mówił Hölderlin. To sama rzeczywistość, w różnych jej przejawach, czyli spekulatywnie opracowywanych fenomenach, zmysłowych zjawiskach, jest dialektyczna, poróżniona, sprzeczna - i w tym znaczeniu logiczna. Logika różnicy pokazuje, że nie chodzi o tępą racjonalność, lecz o ruch pojęć i ruch poetyckich figur, w którym absolut (niemal w sensie etymologicznym, jako całkowita suwerenność, absolvere), nie stanowi żadnego „punktu oparcia”, czegoś, co „chce być przy nas",lecz odsłania się jako istnienie niewyobcowane i wolne, by posłużyć się spekulatywnym żargonem, żyjące „w-sobie-i-dla-siebie”.

W komentarzach do poezji Hölderlina Heidegger idzie znacznie dalej, jakby sama materia wiersza zezwalała mu na odsłonięcie własnych

23 M. Heidegger Heglowskie pojęcie doświadczenia, przeł. R. Marszałek, w: tegoż Drogi lasu, przeł. J. Gierasimiuk i in., Aletheia, Warszawa 1997, s. 113. 
filozoficznych celów. Hölderlin jest dla niego poetą prawdziwie postmetafizycznym, to znaczy wyciąga ostateczne konsekwencje z tezy o śmierci Boga, ale pozostaje poetą religijnym na modłę nieco pogańską - skoro nie ma Boga chrześcijańskiego, pozostają bogowie, którymi może być niemal wszystko: od utraconych bogów greckich po naturę. Toteż poezja Hölderlina z konieczności staje się wyrazicielką nihilistycznego nastroju ogólnego upadku bycia i - właśnie w postaci wierszy - nie głosi nic poza fałszywą nieskończonością językowej (choć już nie logicznej) tautologii: „Dopiero bowiem gdy Hölderlin na nowo ustanawia istotę poezji, ustala na nowo czas. [...] Istota poezji, którą poeta ustanawia, jest w najwyższej mierze dziejowa, antycypuje bowiem czas dziejowy. Jako istota dziejowa jest ona jednak istotną istotą"24.

Tak czy inaczej poezja rodzi się z tego fundamentalnego oddzielenia języka od świata, a konkretna prawda „odsłonięta” w języku przemienia się w fałszywy patos autentyczności. Z kolei właśnie ta separacja jest dokładną odwrotnością praktyki poetyckiej Hölderlina, dla którego dialektyka nie przestaje istnieć, nawet jeśli zostanie zawieszona czy powstrzymana. Temu służą zarówno technika cezury, jak i zasada parataksy - zrywania spekulatywnego, pojęciowego panowania nad światem i przywracania go przez syntaktyczne reguły zestawiania poszczególnych elementów tej rzeczywistości postmetafizycznejej. Seria i szereg zastępują nie tylko liryczność jako sposób wyznania czy ekspresji, ale niweczą teoretyczną fikcję podmiotu i wprowadzają obiektywność z innego porządku - prawdy „poszerzonego” wiersza $^{26}$. Jak mówi Jean-Christophe Bailly, chodzi tu o kres hymnu zarówno jako porządku ontologicznego orzekania, jak i rozwinięcia pisma poetyckiego zupełnie innego - nieznanego - jeszcze typu ${ }^{27}$. Prozodię zastępuje stychiczność:

24 M. Heidegger Hölderlin $i$ istota poezji, w: tegoż Objaśnienia do poezji Hölderlina, przeł. S. Lisiecka, KR, Warszawa 2004, s. 48.

Por. G. Agamben Idea prozy, przeł. E. Górniak Morgan, Fundacja Augusta hrabiego Cieszkowskiego, Warszawa 2018, s. 30-31.

To „poszerzenie" zwłaszcza w przypadku twórczości hymnicznej odbywa się za pomocą, jak pisze Peter Szondi, ,Ja, które nie zna innej tej strzały jak tylko tę boską". Zarazem jednak, o czym świadczy fascynująca analiza filologiczna Szondi'ego, Hölderlin raz po raz pozostawiał luki w różnych szkicach, komentarzach i wersjach danego utworu, tyleż celowe zawieszenia toku poetyckiego, co znaki kresu refleksji prowadzonej w obrębie i za pomocą wiersza. Por. P. Szondi Inna strzała. Początki późnego stylu hymnicznego u Hölderlina, w: tegoż Geometria literatury. Eseje, przeł. Ł. Musiał, Fundacja Augusta hrabiego Cieszkowskiego, Warszawa 2020, s. 89. 
Coś, co pojawia się nagle w zasięgu wzroku, stanowi pierwszą oznakę wiersza. Wiersz się uwidacznia jako taki - jako poezja. Działa niczym wstrząs i rana. Wiersz wciąga nas jakbyśmy doznali wstrząsu, jakby trafiło nas coś, co pochodzi z bardzo daleka, co zstępuje niczym rytmiczne uderzenia i nawet tam, gdzie oddala się od form regularnych, nie przestaje zapowiadać poezji. Naruszając i przerywając wers, poezja wpisuje w przestrzeń proces ponownego rozpoczynania każdej linijki i zapowiada odchylenie w stosunku do linearności prozy: podczas gdy proza zamieszkuje w czasie rozumianym jako kontinuum, wokół którego się owija, wiersz wykracza poza linię czasu. ${ }^{28}$

W tym sensie rację ma Adorno, że wiersz wyłania się z wewnętrznego pęknięcia w samej immanencji świata, zaś artykulacja odbywa się nie poprzez metaforę, ani nawet nie przez obraz, lecz poprzez zapośredniczenie, będące dialektycznym ruchem od wspomnienia (Andenken) do „świadomości nietożsamego przedmiotu"29. Obiektem poezji możemy stać się my sami wciągnięci w wir języka, zapowiadającego już nie zespolenie pojęcia i ducha, lecz pojednania w różnicy, kalejdoskopie różnic, które odciskają się niczym pieczęć na materii wiersza.

Możliwe Inne, zauważa Adorno, zwie się pokojem, pojednaniem - eon przemocy nie zostanie nie unicestwiony, lecz ocalony jako przemijający, w anamnezie echa. Pojednanie bowiem, w którym zależność od natury znajduje swój kres, nie istnieje ponad naturą, jako coś zupełnie innego, co mocą swej inności mogłoby najwyżej znów nad nią panować, poprzez ucisk uczestnicząc w jej przekleństwie. To, co kładzie kres stanowi kres naturalnemu, jest wobec niego zapośredniczone, nie przez element trzeci, pośredni, lecz w samej naturze. ${ }^{30}$

Czy jednak teza ta dotyczy jedynie samego komentarza, podstawowych hermeneutycznych impulsów lub egzegetycznej drobiazgowości? Czy wiersz „czasu odczarowanego" niesie nowość tak skrajną, że nie jesteśmy jej sobie w stanie przyswoić? Czy zatem ta niemożność wcielenia wiersza,

\footnotetext{
28 J.-C. Bailly L'élargissement du poème, Christian Bourgois, Paris 2015, S. 56. Przeł. J.M.

29 T.W. Adorno Parataksa. O późnej liryce Hölderlina, s. 89. 
tak jak inkorporujemy wiedzę o świecie, to, co nieznane - w naturalny bieg życia, jest już doświadczeniem, czy pozostaje tylko martwym i fetyszyzowanym przez niemal całą estetyczną i teoriopoznawczą nowoczesność oporem? ${ }^{31}$. „Opór poezji” polega na podwójnej fałszywej świadomości. Po pierwsze, ważniejsze, nowoczesność estetyczna i epistemologiczna unieważnia hermeneutykę jako nieujawnioną rację oraz zasadę nie tyle tłumaczenia i interpretacji, ile metafizycznego uprawomocnienia, jakie tkwi w pozornej i archaicznej syntezie mechanicznie pojmowanego racjonalizmu i „duchologicznego" świata znaków. Pod tym względem hermeneutyka stanowi ideologię autentycznego doświadczenia poetyckiego jako bezpośredniego wyrazu życia. Ponadto ustanawia fałszywą perspektywę nieskończoności języka, który trwa, póki trwa niezatarta inskrypcja poezji lub ślad czy zarys definiującego ją obrazu ${ }^{32}$. Po drugie, to ideologiczne zafałszowanie świadomości literackiej, a w konsekwencji utajona i znaturalizowana przemoc wobec samej poezji i stworzonego przezeń świata opierają się na wizji dziejów, która zastępują konkret historycznej zmiany. W efekcie wiersz staje się albo odseparowaną formą obecności, jako pisma i jako ducha, albo formą mitologii, której autorki i autorzy tworzą piętrzące się warstwy tego samego świata, o zmiennych funkcjach i w zmiennych wariantach. Duch i litera, tożsamość mitu i fałszywe różnice, czy - jak powiada przenikliwe Freud - „narcyzmy małych różnic” są tyleż świadectwem rozpaczliwej bezradności odsłaniającej się w komentarzach do wierszy tak osobliwych, że niejako w nich samych, w ich substancji, materii, zmysłowości, powstają nowe miejsca naszej wiedzy. Poezja nowoczesna nie jest już liryką w takim znaczeniu, że liryczność jako zasada i jako warunek nie tkwi już w jej nowoczesnych formach. Nawet więcej: liryczność oznacza kres poezji jako formy uobecniającego się ducha i subiektywności - w ich syntezie lub w ich separacji.

Toteż nie ma racji Jacques Derrida, twierdząc, że literatura nowoczesna jako najdoskonalsza forma refleksji opiera się na podwójnym pojęciu

31 J.-L. Nancy Résistance de la poésie, William Blake \& Co, Paris 1997.

32 ")ęzyk nauki jest jedynie pewnym zintegrowanym tworem w obrębie całości żywego języka; zaś nade wszystko istnieją takie rodzaje słowa jak te, z jakimi obcujemy w języku filozoficznym, religijnym i poetyckim. W każdym z nich słowo jest czymś więcej niż zapominającą o sobie drogą ku światu. Zamieszkujemy w języku. Jest on rodzajem rękojmi tego, o czym mówi. Szczególnie jasno ilustruje to poetyckie użycie języka". H.-G. Gadamer /ęzyki rozumienie, w: tegoż/ęzyk i rozumienie, przeł. P. Dehnel, B. Sierocka, KR, Warszawa 2003, s. 24. 
inwencji - jako wynajdywaniu i wytwarzaniu sensów ${ }^{33}$. Inwencja - wtórna wobec instynktownego i cielesnego włączenia się w pole „innej wiedzy” wiersza, czytanie go jako "protokołu osobliwości” - odsłania swoją niewystarczalność właśnie tam, gdzie, jak się zdaje filozofowi, dekonstrukcyjny dublet święci triumfy, ustanawiając ontologię zależną wyłącznie od dwóch stanów pisma jako formy myśli. Nowoczesność radykalna również i te postmetafizyczne dylematy już od dawna zostawiła za sobą: dekonstrukcja, pasożytniczo żywiąca się logiczną aporią, nie tyle blokuje możność poznania, ile koncentruje się na warunkach możliwości jako referencji. Innymi słowy, nie unieważnia (zdroworozsądkowych) odniesień tekstu do rzeczywistości, lecz w sposób fantastyczny, ale zupełnie niewczesny i błędny pomija szczególny moment w samej lekturze, w którym wiersz odsłania własną prawdę jako urzeczywistnienie refleksji poznawczej. Toteż dekonstrukcję jedynie formalnie można uznać za język krytyczny; w sfingowanym rytmie fałszywej nieskończoności ustanawia równie fantasmagoryczną i nieprzekraczalną granicę oddzielającą poznanie od doświadczenia, to zaś od konkretnej prawdy. Innymi słowy, rozumienie pisma jako inskrypcji, która, by tak rzec, betonuje głos, i głos, który dezaktywuje literę, stanowi niemal dokładne odwrócenie genialnej intuicji Kanta, ustanawiającej regułę krytycznego rozumu. Dość przypomnieć w tym kontekście pojęcie przedmiotu myślowego (noumenu), czyli rzeczy samej w sobie, która nie jest wcale sprzeczna wewnętrznie, lecz stanowi „negatywne rozszerzenie” naoczności, a zatem jest po prostu odgraniczeniem tego, co pomyślane w ogóle, od tego, co pomyśleć się nie da. Jeśli więc krytyczne poznanie stanowi granicę, a różne epistemologiczne aktywności o nią się potykają, nie oznacza to wcale, że każdy rodzaj, czy nawet każdy akt, owa dynamika poznawania, skazane są na niemożność aporii34.

Właśnie w tym sensie dekonstrukcja poezji nowoczesnej (jako artykulacji nowoczesnej wielości) nie działa - zarówno w sensie strategii lektury, jak i twórczego demontażu pojęcia. Widać to może najpełniej w analizie poezji Celana, celowo ograniczonej przez Derridę do kilku podstawowych aporii, których proces odkrywania i wynajdywania nie prowadzi w stronę rzeczywistej inności, lecz ją formalizuje tym bardziej, im więcej odkrywa ukrytych założeń poszczególnych gestów poetyckich. Tymczasem ta podejrzliwość, co ciekawe, ale niestety konsekwentne bardziej logiczna niż tropologiczna,

33 Por. J. Derrida Psyché. Invention de l'autre, w: tegoż Psyché. Inventions de l'autre, Galilée, Paris 1987.

Por. I. Kant Krytyka czystego rozumu, t. 1, przeł. R. Ingarden, PWN, Warszawa 1957, s. 443-450. 
przynosi pojęcia, które przychodzą do świata wiersza skądinąd ${ }^{35}$. Nie powinniśmy się dziwić, że wyłuskiwane przez Derridę pojedyncze tematy są osobliwościami definiującymi poezję jedynie logicznie, ale już nie praktycznie, jednostkowości zostają bowiem zneutralizowane niejako zawczasu, stając się martwymi dla lektury wiersza inwersjami między warunkami możliwości i niemożliwości.

Czy może zatem dziwić, że pojedynczości wiersza, owej obsesji Derridy, nie sposób ujawnić, gdyż trwa w mało ciekawym napięciu między idiomem a instytucją? Właśnie tu, jak się zdaje, tkwi najpoważniejszy błąd dekonstrukcji, który na pewnym poziomie stanowi po prostu błąd kategorialny (a priori wzięte za a posteriori i na odwrót), ale przede wszystkim polega na unicestwieniu czasowej dialektyki poezji. Mówiąc za Kantem, wiersz jest istotnie rzeczą samą w sobie, ale jego negatywna graniczność może ujawnić się czy dojść do głosu jednie w konkrecie historycznej prawdy. Derrida, fantastycznie ukazując największy sekret Celana, czyli datę, natychmiast likwiduje jego konkretność, sprowadzając owo traumatyczno-życiodajne i historiozoficzne zarazem doświadczenie, którym staje się ona sama, do przewidywalnej, niemal scholastycznej maszynerii rozumu. Data u Celana nie jest bowiem pojęciem znamienia ani znamieniem wyłącznie cielesnym, punktem zetknięcia i znikania, zakreślania granic świata oraz ich anihilacji. Derrida tymczasem twierdzi:

Podobnie jak physis data lubi się kryptonimować. Musi się zatrzeć, aby mogła stać się czytelną, stać się nieczytelną w samej swej czytelności. Ponieważ jeśli nie zawiesi w sobie tej unikalnej cechy, która uzależnia ją od zdarzenia bez świadka, bez innego świadka, to pozostaje nietknięta, ale też zupełnie nieodszyfrowalna. Nie jest więc nawet czymś więcej niż tym, czym ma być, czym powinna była być, swą istotą i swoim przeznaczeniem, nie dotrzymuje już więcej swego słowa, słowa daty. ${ }^{36}$

Derrida niczym mistagog sugeruje, że ślad pozostawiony w językowym archiwum i zapieczętowany w mrocznej krypcie to ostatnia i ostateczna sankcja różnych podmiotowości. Nie inaczej wiersz, który przywalony ruinami sensów i znaków mówi coś, co może świadczyć tylko o własnej niemożliwości.

35 Por. znakomite analizy Pascala Quignarda, w: tegoż Critique du jugement, Galilée, Paris 2015. Przeł. J.M.

36 J. Derrida Szibbolet. Dla Paula Celana, przeł. A. Dziadek, Fa-art, Katowice 2000, s. 18. 
Dekonstrukcja jako mistagogia to taniec nad przepaścią wiedzy narcystycznej, której nie należy szukać (w każdym razie nie wyłącznie) w porządku mowy, ani w jej głęboko schowanym sercu, mówiącym za siebie poemacie, który znamy niejako „na pamięć" ${ }^{37}$. Jeśli bowiem poezja nowoczesna wyrzeka się subiektywności, to nie oznacza, jak chciałby Derrida, że zostaje pozbawiona ekspresji ${ }^{38}$. Wręcz przeciwnie: ekspresja stanowi składnik poezji, która właśnie z tego powodu nie ogranicza się ani do metafory (ulubionego tropu podlegającego dekonstrukcji), ani do metonimicznego spłaszczenia, lecz w samym swym ruchu wypowiada przynależne jej pojęcie. Świadectwo wiersza nie może zatem przestrzegać tylko jednej reguły, czyli etycznej wiarygodności jednostki, będącej niemal matematyczną granicą wypowiadalności, a zatem i kresem procesu dekonstrukcji znaczeń.

A przecież takie restrykcyjne traktowanie świadectwa do pewnego stopnia je delegitymizuje, w każdym razie poważnie podważa i narusza, wiersz może być zarówno świadectwem, jak i świadkiem, to znaczy obiektywizuje się w wiedzy, zawsze określonej i co do zasady konkretnej (historycznie, politycznie, społecznie, poetologicznie itd.). Nie jest to wszelako wiedza pewna nauki, lecz drżące poznanie dające szansę, a nawet ucieleśniające niepewność: „Istnieje byt jako sens, byt oderwany od stałej życiodajnej podstawy, od ustalonego określenia oraz od przyswojenia bycia przez podmiot. Niepewność negatywności to ruch, wzburzenie i napięcia, ból i radość z tego przywłaszczenia"39. Taka wiedza nie znajduje się zatem poza wierszem (w jakimś zewnętrzu), lecz jest zawarta w samej poezji jako formie ekspresji wiedzy i niepewności, świadectwa, która nie daje się umieścić w archiwum dopóty, dopóki wiersz żyje własnymi sprzecznościami, a nie martwymi aporiami. O ile wiersz - jak powiada Jean-Luc Nancy - jest sprzeciwem (a nie jego znakiem czy śladem), o tyle pozostaje ruchem myśli - przed którym stajemy, zanim wiersz nas dotknie, jak i wtedy, gdy lektura zostanie ukończona. Ten ruch to spekulacja we właściwym sensie, wieczny niepokój, wibracja słowa i ciała, zmysłów i pojęć, znoszących wszelki determinizm - największego wroga nowoczesnej poezji, w której niewczesność wdziera się w aktualność jej wymowy, niespodziewanej artykulacji. Jak pisze Nancy:

Chodzi w tym miejscu o nieprzetłumaczalną grę słów: „par cœur" - "na pamięć" i dosłownie "z serca" czy "przez serce”. 
Dusza jako taka to głos wołający w innym. W ten sposób wzywa ona podmiot, choć go jeszcze nigdzie nie umieszcza. Przeciwnie: unika go. Nie nazywa duszy we wzajemnym rozumieniu, we współdzielonej słyszalności, ani w żadnym dyskursie. Wzywa, co oznacza jedynie, że wprawia głos w drżenie, że go porusza. To właśnie dusza uwalnia innego w niej samej. Tym właśnie jest głos. ${ }^{40}$

Nawet jeśli duch poprzedza materię, a zatem nawet jeśli ciało pozostaje oddzielone od ducha "przed” wierszem (w podwójnym sensie: topologicznym i temporalnym), to owa „drżąca” niepewność jest warunkiem ontologii wiersza. W ten sposób „kryzys wiersza”, wieszczony przez Mallarmégo, dotyczy nie tyle napięcia między autonomią a heteronomią poezji, między milczeniem a intersubiektywnością, skamieniałą materialnością litery i jej funkcjonalnością a polityką słów ${ }^{41}$, ile pisania i lektury dzielących się wewnątrz samych siebie, wykraczających poza siebie i do siebie powracających, niemal według rytmu skurczu i rozkurczu „serca” wiersza ${ }^{42}$. Jesteśmy więc wrzuceni w sam środek czasu, w zawęźlenie temporalności, czasu, który - jak powiadał Kant - ostatecznie okazuje się „samą przemocą” czystego obrazu ${ }^{43}$, determinującego wszelkie inne obrazy, w tym i te, które tworzą najbardziej syntetyczną jego formę, czyli wiersz - już poza zasadą liryczności, lecz jako transcendentalne warunki poznania. Wydaje się jednak, że taka wizja poezji nowoczesnej jest nazbyt statyczna, stanowi jeden z elementów perfekcyjnej maszynerii epistemologicznej. Zapisuje się, jak można sobie to wyobrazić, niczym znak na tablicy antynomii rozumu, między czystym czasem i czystą przestrzenią a perfekcyjnym sądem smaku, który wraca sam do siebie, stając się na koniec najistotniejszym stanem, w jaki człowiek może się zamienić - w kontemplację.

Podmiot, który patrząc, nie widzi obiektu własnego spojrzenia, czytając, nie słyszy własnego głosu, rezonującego zdematerializowanym pismem, nie jest jednak czystą rozumnością, może bowiem odczuwać przyjemność z samej

40 J.-L. Nancy Vox clamans in deserto, w: tegoż Le poids d'une pensée, I'approche, La Phocide, Strasbourg 2008, s. 36 .

Por. J. Rancière La politique de la littérature, Galilée, Paris 2007; Q. Meillassoux Syrena i liczba. Rozszyfrowanie Rzutu kośćmi Stéphane'a Mallarmégo, przeł. P. Herbich, Fundacja Augusta hrabiego Cieszkowskiego, Warszawa 2019.

Por. I. Kant Metafizyka moralności, przeł. E. Nowak, PWN, Warszawa 2005, §42, §52, § 62. 
pozycji, jaką zajmuje. Ten perwersyjny rdzeń kantowskiego systemu, który stał się jasny za sprawą Adorna i Lacana ${ }^{44}$, powoduje, że poezja staje się niezmąconym niezróżnicowaniem lub martwym osadem pisma, będącym czystym wyobcowaniem języka w najwyższym stopniu - nie jest ani figurą, ani pojęciem. Pozbawiona mocy metaforycznej i określającej, zamienia się w beznamiętną i nudną listę ekscesów, obojętniejących w jednostajnym szmerze mowy. Bodaj właśnie dlatego najpełniejszym przykładem takiej anihilacji języka jest transgresja erotyczna - wiersza jako miłości. W tej perspektywie seksualna rozkosz staje się obowiązkiem moralnym, tyle tylko, że podanym w odwróconej formie permisywnego nakazu, głoszącego, że dopuszcza się jedynie takie przekroczenie, które ustanawia porządek fantazji, a nie realnego doświadczenia. Toteż odwrócony imperatyw kategoryczny tyleż wyobcowuje podmioty, co zniekształca język, składający się ze zdań protokolarnych, będących dość prostą antytezą cielesnej bezforemności.

Kantowski paradygmat estetyczny, mocniejszy niż się na pozór wydaje, prowadzi jednak głównie w stronę legitymizacji filozofii jako nauki w sensie ścisłym, pozostawiając przedmiot doświadczenia zmysłowego jako kruchy obiekt, który znika wraz z pojawieniem się pojęcia nasycającego go od zewnątrz. Kant ma rację, twierdząc, że realność sądu estetycznego opiera się na relacji, ale nie ma racji, gdy mówi, że cała prawda tego sądu zawiera się tylko w modalnościach orzekania. Możemy kontemplować malowidło, utwór muzyczny lub rzeźbę, każde według jego własnego, inherentnego sposobu, ale - w tym rozumieniu - nie da się kontemplować wiersza. Właśnie w tym miejscu docieramy do ślepej plamki idealistycznego dyskursu krytycznego. Poezja wytwarza rodzaj wiedzy niepasującej do wiedzy kategorialnej: tam, gdzie Kant chciałby wiedzieć, co znaczy wiersz, czym są składające się na niego znaki, widzi jedynie zagmatwane i piękne w swej nieistotności arabeski.

Nowoczesny wiersz nie jest liryczny w sensie teoriopoznawczym, gdyż wiedza, którą otwiera jako możliwość innego życia, przemienia się w doświadczenie - poezja porusza, jest emotywna, ale nie w sensie afektywnego pragmatyzmu i skuteczności psychicznego odreagowania, lecz dlatego, że spotkanie myśli, obrazu i figury staje się nieuchronne i nieprzewidywalne zarazem, skończone w swej materialności i nieskończone w swej przypadkowości. Myśl-w-wierszu to stan ducha, tak jak stan pogody, naturalny

44 Por. M. Horkheimer, T.W. Adorno Dialektyka oświecenia. Fragmenty filozoficzne, przeł. M. Łukasiewicz, Krytyka Polityczna, Warszawa 2010; J. Lacan Kanta Sadem, przeł. T. Komendant, „Twórczość" $1989 \mathrm{nr} 8$. 
i niezbywalny, ale też jest to nieprzewidywalność zdarzenia, którego siły oraz intensywność jesteśmy przewidzieć tylko w ograniczonym stopniu. Być może tak właśnie przebiegałoby doświadczenie poetyckie: jednostronne w swej czasowości i odnawialne w swej przypadkowości. Być może także trzeba włączyć materialistyczną dialektykę wiersza, której elementarnym doświadczeniem jest przeżycie chwilowego zawieszenia sensów, języka i zmysłów, momentalnego przesunięcia w obrębie obrazu, nieuchronnie nam umykającego, ale i przemieszczenia dającego nadzieję, że następny spekulatywny ruch, uwalniający na nowo, inaczej ten sam obraz. Innymi słowy, poezja-myśl mieściłaby się w chwili, w której językowa forma Idei dopiero się wyłania, kształtując - rzecz jasna - nas samych: percepcyjnie, zmysłowo, kognitywnie i politycznie. Tam, gdzie liryka osiaga swój kres w postaci doskonałości sensu lub doskonałości procedur jego utraty (to odwieczny temat modernistycznych prób odzyskania mocy poezji: od Mallarmégo, Rilkego, przez Celana, Różewicza do Sosnowskiego i Ashbery'ego, co w sensie historycznym stanowiłoby „wiek poetów”45), tam zaczyna się nieodwracalna logika osobliwości, dla których tylko w poezji można znaleźć miejsce. Z pewnością sporo jest prawdy w poetyckiej doksie, głoszącej, że nowoczesność poetycka opiera się na stosunkowo stabilnej mechanice antytez ciągłości i zerwania.

Ale sama ta antytetyczność działa niemal mikrologicznie, na poziomie zdarzeniowości samego wiersza. W ten sposób poezja-myśl nigdy nie może zostać swą własną odwrotnością (o czym marzył Derrida), ponieważ dialektyka dosłownie „nie traci czasu”, dzięki czemu unikamy banalnej dychotomii utraty i odzyskania, tradycji i awangardy. Działanie tego mechanizmu wystawia nas na działanie „dowcipu zdarzenia”, który na jedną chwilę staje się zawrotem głowy, szaleństwem możliwości słów i obrazów, unieważnieniem czasu i otchłanią przyjemności. Czy można chcieć czegoś więcej od poezji? Łącząc w sobie kalejdoskopową logikę pojęć z rauszem lektury lub/i pisania, poezja jest ekspozycją gry, jednak nie takiej, o jakiej myślał Kant (wolnej gry wszystkich władz i sądów), lecz gry spekulatywnej, czyli zniesienia (Aufhebung). Inaczej zatem niż można by przypuszczać, spekulacja nie jest czczym mnożeniem kategorii, w niczym nie przypomina scholastycznego rozumu, lecz jest życiem samym, w którym natrafiamy - najpełniej może właśnie dzięki poezji - na chwile, w których stajemy się naprawdę wolni: widzimy cały świat, jak mówi poetka, w „ziarnku piasku”. Wiersz spekulatywny

45 Pożyczam tę formułę od Alaina Badiou. Por. A. Badiou Manifesty dla filozofii, przeł. A. Wasilewski, PWN, Warszawa 2009, s. 57-66. 
to zatem nowoczesna forma przygodności. Inaczej niż w wielkiej tradycji zapoczątkowanej przez Mallarmégo nie chodzi o „zniesienie przypadku”,lecz o kategorię egzystencjalną, czyli przygodność. W przypadku autora Igitura mamy do czynienia, jak trafnie podsumował problem Alain Badiou, z „zasadniczą ideą":

Wiersz nie jest ani deskrypcją, ani ekspresją. Nie jest też poruszonym malowaniem przestrzeni świat. Poemat jest operacją. Naucza nas, że świat nie prezentuje się jako zbiór obiektów. Świat nie wysuwa obiekcji wobec myślenia. Jego obecność - dla operacji poematu - jest bardziej esencjonalna niż obiektywność. ${ }^{46}$

Tymczasem w tradycji krytycznej istnienie dzięki poezji może zostać ocalone i może w pełni się wyartykułować za sprawą tego przejścia od losowości, ontologicznego indeterminizmu do indywidualnego życia jako uświadomienia, a nawet ucieleśnienia własnej kontyngencji. Jak pisał Nancy, chodzi o to, że „przypadkowość form jest ich prawdą" ${ }^{47}$. Nie o to, by poezja mówiła wyłącznie za siebie, albo podporządkowała się rozmaitym instytucjom komentarza, lecz o to, że mówienie indywidualne, zajmowanie pozycji pozostaje zawsze zakotwiczone w polu uniwersalności. Na tym polega osobliwość naszych egzystencji, na tym także opiera się jednostkowa uniwersalność radykalnych form poetyckich.

46 A. Badiou Mały podręcznik inestetyki, przeł. A. Wasilewski, Wydawnictwo Naukowe UAM Poznań 2015, s. 41.

47 J.-L. Nancy La remarque spéculative. Un bon mot de Hegel, Galilée, Paris 1973, s. 176-177. 


\section{Abstract}

\section{Jakub Momro}

JAGIELLONIAN UNIVERSITY (CRACOW)

Knowledge in the Poem: The Philosophy of Postlyrical Times

Momro presents a genealogy of poetry in postlyrical times. The idealistic sources of poetry as knowledge and power of judgment become a point of departure to explore two models of the modern poem: the contemplative and the speculative one. In the first part an analysis of Friedrich Hölderlin's work indicates the strengths and limitations of poetry as a discourse of "other knowledge," while in the second part Momro demonstrates the limitations of deconstructive readings. Eventually, the text's key problem is one of singularity and randomness of the modern poem.

\section{Keywords}

speculation, contemplation, singularity, randomness, epistemology of the poem 